\title{
PEMASARAN PARIWISATA MELALUI KEMASAN PRODUK UKM STANDING POUCH BERBAHAN PAPER METAL DI ERA EKONOMI KREATIF
}

\author{
Nidyah Widyamurti \\ Fakultas Seni Rupa dan Desain (FSRD), Universitas Sebelas Maret, Surakarta \\ Jl. Ir. Sutami No.36, Kentingan, Kec. Jebres, Kota Surakarta \\ E-mail Korespondensi: nidyah1234567890@gmail.com
}

\begin{abstract}
ABSTRAK
Berdasarkan pertimbangan pada kemudahan produksi, perlindungan atas produk, daya tarik visual, dan sebagainya, kemasan standing pouch berbahan paper metal diminati UKM untuk mengemas produknya. Kemasan standing pouch adalah kemasan yang terbuat dari bahan kertas cetak yang dilapisi plastik metalize atau alumunium foil di bagian dalamnya.Kemasan ini tidak hanya bersifat melindungi produk dalam rantai distribusi hingga sampai ke tangan konsumen,tetapi mampu menjadi daya dukung utama dalam pemasaran produk ketika produk didisplay di suatu toko, serta efektif sebagai media promosi pariwisata. Penelitian ini merupakan penelitian kualitatif yang bertujuan mengkaji jenis kemasan dan daya tarik desain grafis bagi konsumen, terutama sebagai media promosi pariwisata. Metode penelitian adalah Studi Kasus. Penelitian dilakukan dengan latar alamiah, holistik, dan mendalam yang dianalisis dengan menggunakan Trianggulasi Data. Hasil penelitian ini berupa konsep desain kemasan jenis standing pouch berbahan paper metalyang tepat untuk mendukung pemasaran produk UKM dan kepariwisataan di era ekonomi kreatif saat ini.
\end{abstract}

Kata Kunci : Kewirausahaan, Kemasan, Produk UKM, Pemasaran Pariwisata

\begin{abstract}
Considering its easy production process, protective capaticity, visual appeal, and so on, many SMEs choose standing pouch packaging made from paper metal to pack their products. This packaging enhances product appearance to be more attractive when displayed in a store. A standing pouch packaging is a packaging made of paper-coated with metalize plastic or aluminum foil on the inside. This packaging not only protects the product in the distribution chain until it reaches the consumers' hands, but also serves as main appeal in the products' marketing when they are displayed in a store. This study is a qualitative research that aims to examine the types of packaging and the appealing value of their graphic design to the consumers, especially as a media of tourism promotion. The research method is Case Study. The research was conducted with a natural, holistic, and in-depth background. The datawere analyzed using Data Triangulation. The result of this research is a design concept of standing pouch packaging made from paper metal that has appealing value to support the marketing program of SME products and tourism in the current era of creative economy.
\end{abstract}

Keywords: Entrepreuneurship, Packaging, SME Products, Tourism Marketing 


\section{PENDAHULUAN}

Pariwisata merupakan salah satau penggerak perekonomian dunia yang terbukti mampu memberikan kontribusi terhadap kemakmuran sebuah negara. Pembangunan pariwisata mampu menggairahkan aktivitas bisnis untuk menghasilkan manfaat sosial, budaya, dan ekonomi yang signifikan bagi suatu negara (Rai, 2017:6). Sebagai suatu produk, pengembangan sektor pariwisata perlu didukung oleh program pemasaran. Strategi pemasaran pariwisata biasa diapliksikan melalui beragam conventional mediaseperti media cetak, media elektronik, media outdoor, media digital, dan lain sebagainya, serta unconventional media lainnya.Setiap daerah/wilayah wisata pasti mempunyai produk-produk yang dikemas dengan kemasan yang unik sesuai dengan ciri khas daerah/wilayah tersebut, dengan harapan jika wisatawan membelinya sebagai oleholeh atau sekedar mendokumentasikannya melalui media sosial akan bisa mendukung pemasaran daerah/wilayah wisata tersebut kepada audiens yang lebih luas.

Kemasan makanan berbentuk standing pouch berbahan paper metal merupakan jenis kemasan kekinian. Bahan paper metal merupakan bahan yang terbuat dari lapisan paper (kertas) dan metalize atau aluminium foil (alufoil). Lapisan metalize ini mencegah cairan dan minyak menembus permukaan luar kemasan, dan melindungi produk dari kelembaban, udara, bau, cahaya, dan mikroorganisme dan cocok digunakan untuk mengemas produk makanan. Sementara lapisan kertas (paper) pada bagian luar yang memungkinkan brand dicetak dengan kualitas full colordengan kualitas baik dan performa yang menarik. Kemasan berbentuk standing pouch berbahan paper metal sedang trend digunakan UKM saat ini karena relatif menarik untuk mengemas produk-produk mereka yang biasanya berupa makanan kecil seperti: keripik, manisan, asinan, kuaci, roti kering, dodol, dan lain sebagainya. Proses produksinya relatif mudah dan murah, sehingga membutuhkan anggaran yang terjangkau, bisa dipesan dalam skala kecil (minimal 10002000 pcs) disesuaikan dengan kapasitas produksi UKM tersebut;tersedia dalam berbagai varian bentuk kemasan,ukuran paling kecil adalah 70 gram, dan ukuran terbesarnya adalah 1 kilogram. Kemasan dengan ukuran 100 gram, 150 gram, 250 gram, dan 500 gram bisa dipesan sesuai kebutuhan. Kemasan paper metal mampu mengemas produk dengan baik, aman, dan nyaman digenggam ketika konsumen akan mengonsumsinya.

Di era ekonomi kreatif saat ini, pemerintah mendukung pengembangan sumber daya alam (SDA) berbasis gagasan kreatif dari sumber daya manusia (SDM) yang dimiliki setiap daerah. UKM bermunculan dengan berbagai produk unggulannya. Beberapa dari UKM tersebut memproduksi produk (makanan) yang mencirikan kaunggulan/karakteristik daerah tertentu. Bagi bidang pariwisata hal itu merupakan daya dukung yang luar biasa, karena melalui produk olahan yang berasal dari SDA lokal mampu diandalkan sebagai sumber pendapatan warga dan memperkuat branding daerah/ wilayah wisata setempat. Hanya saja, kekuatan produk perlu didukung dengan media yang tepat. Dari aspek pemasaran, kemasan merupakan media yang paling tepat sebagai ujung tombak pencitraan (branding) dan aktivitas pemasaran (marketing). 


\section{METODE PENELITIAN}

Penelitian ini menggunakan pendekatan kualitatif dengan metode Action Research. Action research merupakan suatu proses demokratis dan partisipatorik yang menyangkut pengembangan pengetahuan praktis dalam upaya mencari tujuan yang bermafaat bagi kemaslahatan kehidupan di dunia (Coghlan and Bannick, 2005 dalam M.Yaumi, 2014).

Pengumpulan data dilakukan dengan metode indepth interview, mempelajari beberapa kemasan standing pouch berbahan paper metal sebagai bahan penelitian, dan studi dokumen yang relevan. Analisis data dilakukan menggunakan pendekatan analisis interaktif dengan latar alamiah, holistik, dan mendalam yang dianalisis dengan menggunakan Trianggulasi Data.Sumber data dalam penelitian ini berasal dari kemasan standing pouch berbahan paper metalsebagaikemasan produk makanan UKM yang mencantumkan identitas daerah/wilayah sebagai elemen desain kemasannya. Proses eksplorasi dilakukan atas karya-karya desain kemasan berbentuk kemasan standing pouch berbahan paper metal hasil karya desain yang diposting di akun Instagram Rumah Kemasan Bandung (@ rumahkemasanbandung), Kemasan Masa Kini Paper Foil (@kemasan_masa_kini), Desain Logo dan Desain Kemasan (@assiasoft), dan Kemasan Paper Foil \& Dus UKM (@ruangkemasan).

Dokumen yang digunakan sebagai sumber data adalah sumber referensi terkait dengan pemasaran pariwisata, kemasan produk UKM, kemasan standing pouch berbahan paper metal, dan ekonomi kreatif.

\section{HASIL DAN PEMBAHASAN}

Dalam era ekonomi kreatif, sub sektor industri kreatif Kuliner menghasilkan UKMUKM yang memproduksi makanan dan jajanan yang bervariasi. SDM lokal mengolah SDA setempat menjadi produk-produk kuliner yang kreatif dan bernilai ekonomis.

Dalam laman PresidenRI.go.id (www.presidenri.go.id) dipaparkan bahwa ada sebanyak 56 juta UKM di Indonesia dan $70 \%$ diantaranya terdiri dari UKM pangan. UKM terbukti memiliki kemampuan dan potensi menjadi penggerak ekonomi. Presiden Joko Widodo mendorong produk UKM untuk mampu menembus pasar global. Salah satu cara yang disarankan adalah memberikan perhatian khusus kepada kemasan suatu produk,karena kemasan yang menarik akan mampu menarik perhatian konsumen, apalagi jika produk sudah siap untuk masuk ke pasar ekspor.

Satu daya tarik dari produk UKM adalah mereka merupakan SDM-SDM kreatif lokal yang mampu mengeksplorasi SDA menjadi produk yang kreatif dan menarik, sehingga bisa dikatakan bahwa produk UKM rata-rata menyajikan kekayaan SDA setempat yang diolah menjadi produk yang khas. Kemasan standing pouch berbahan paper metal sedang menjadi tren untuk mengemas produk UKM. Kemasan jenis ini banyak dipilih UKM karena nilai ekonomis dan daya tarik visual yang bisa ditampilkan pada permukaannya.Berikut beberapa contoh kemasan standing pouch berbahan paper metal yang menarik perhatian konsumen: 


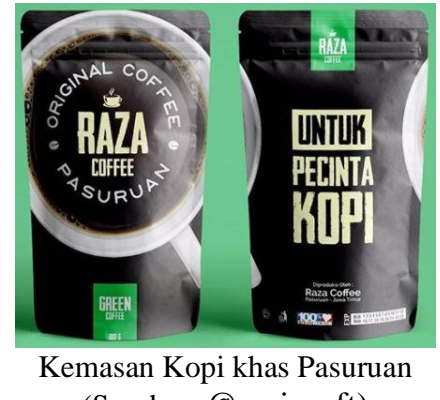
(Sumber: @assiasoft)

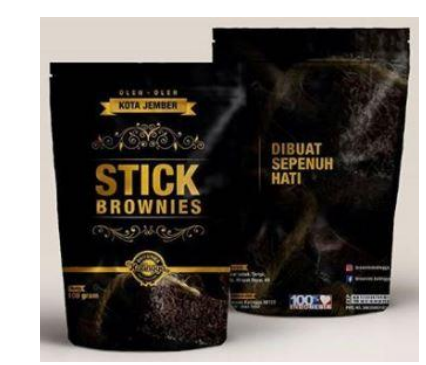

Kemasan Stik Brownies kota Jember (Sumber: @assiasoft)

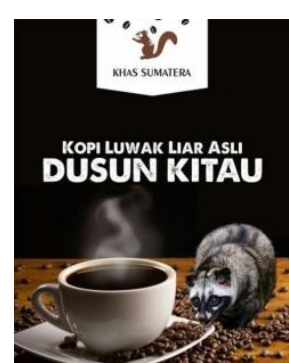

Kemasan Kopi Luwak khas Sumatera (Sumber:@kemasan_masa_kini)

Gambar 1. Kemasan Karya "Desain Logo dan Desain Kemasan” Identitas daerah/wilayah dicantumkan dalam bentuk tulisan/informasi verbal

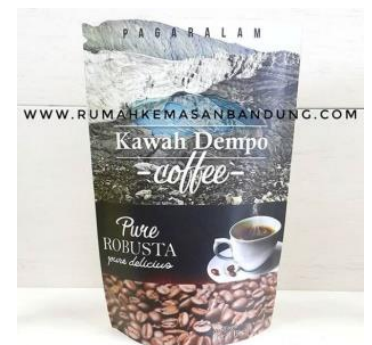

Kemasan Kopi Robusta khas Pagaralam

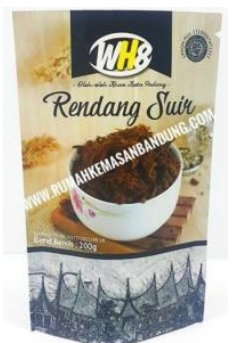

Kemasan Rendang khas Kota Padang

Gambar 2. Kemasan Karya "Rumah Kemasan Bandung” Identitas daerah/wilayah dicantumkan dalam bentuk ilustrasi/foto

(Sumber: Instagram @ rumahkemasanbandung)

\section{Elemen Desain Grafis Pada Kemasan}

Desain kemasan adalah visual perwajahan, bentuk, bahan, dan pencitraan yang ingin ditampilkan pada sebuah kemasan untuk meningkatkan performa produk. Bagi produk, kemasan bukan sekedar sebagai pembungkus semata, tetapi berperan juga sebagai alat bantu pemasaran, pencitraan produk, menampilkan identitas, legalitas, dan sebagai sumber informasi produk kepada konsumen. Pada era ini, produk dibeli tidak sekedar berdasarkan fungsi kemanfaatannya saja (functional benefit), akan tetapi juga dibeli atas alasan fungsi emosionalnya (emotional benefit).

Tabel 1. Functional Benefit dan Emotional Benefit

\begin{tabular}{|l|l|}
\hline \multicolumn{1}{|c|}{ Functional Benefit } & \multicolumn{1}{c|}{ Emotional Benefit } \\
\hline \hline Kemasan bisa memenuhi semua fungsi & Kemasan secara emosional akan \\
utamanya sebagai pengemas, & membuat konsumen merasa puas dan \\
pelindung, media informasi, alat & bangga, atau merasakan nilai (value) \\
distribusi dalam proses pembelian, dan & $\begin{array}{l}\text { atas pembelian dan penggunaan suatu } \\
\text { fungsi primer lainnya. }\end{array}$ \\
produk.
\end{tabular}


Bahkan Hermawan Kartajaya menegaskan bahwa saat ini merupakan era dimana kemasan melindungi apa yang dijual, sekaligus kemasan menjual apa yang dilindungi. Dengan demikian, kemasan bukan lagi sebagai pelindung/wadah semata, tetapi juga mampu menjual produk yang dikemasnya. Untuk itu, kunci yang utama adalah informasi apa saja yang perlu dicantumkan dalam kemasan dan bagaimana visualisasi kemasan bisa menarik perhatian konsumen.

Informasi yang tercantum bisa dalam bentuk elemen verbal, elemen visual, maupun dalam bentuk invisible element. Elemen desain tidak hanya berfungsi sebagai identitas dan informasi produk saja, akan tetapi juga berfungsi sebagai legalitas dan alat kontrol bagi pemerintah untuk melakukan pengwasan atas peredaran produk tersebut di pasaran.Dasar hukum tentang kemasan produk pangan antara lain:

1) Undang-Undang RI No.18 Tahun 2012 tentang Pangan

2) Peraturan Pemerintah RI No. 69 Tahun 1999 tentang Label dan Iklan Pangan

3) Peraturan Pemerintah No.28 Tahun 2004 tentang Keamanan Mutu dan Gizi Pangan

4) Peraturan Kepala Badan Pengawas Obat dan Makanan (BPOM) Republik Indonesia Nomor : Hk 00.05.55.6497 tentang Bahan Kemasan Pangan

5) Peraturan Menteri Kesehatan RI No.329/Menkes/XII/76 tentang Produksi dan Peredaran Pangan

Dalam desain kemasan, informasi tentang segala hal yang perlu diketahui konsumen tercantum pada kemasan, diantaranya:

1) Brand Name/Logo/Merek Dagang

2) Nama Produkyang didesain dengan tipografi yang menarik, ukuran besar, dan warna yang kontras.

3) Kategori Produk yang penulisan dan pencantumannya disertakan dalam satu desain dengan Nama Produk atau terpisah dalam bentuk kalimat tersendiri.

4) Ilustrasisebagaiimage utama yang digunakan dalam desain kemasan yang memberikan gambaran atas produk yang dikemas didalamnya.

5) Background/Gambar Latar menunjukkan ilustrasi yang memperkuat penampilan kemasan. Penggunaannya bisa full pada seluruh bagian kemasan atau pada sebagiannya saja.

6) Logo Halal berupa sertifikasi Halal MUI sebagai legalitas kehalalan suatu produk oleh Pemerintah atau legalitas dari lembaga lain yang terkait.

7) Informasi Berat Kotor, Berat Bersih, Isi Kotor, Isi Bersih produk.

8) Identitas Produsen dan Distributor yang diwujudkan dengan alamat lengkap hingga ruang layanan konsumen.

9) Komposisi Produk berupa informasi tentang susunan bahan bakuproduk dan sifatnya wajib untuk produk pangan.

10) BPPOM sebagai izin tertinggi di Indonesia yang harus dan wajib dimiliki setiap produk obat-obatan, kosmetik, suplemen makanan, dan jamu yang beredar secara bebas.

11) PIRT, MD, ML, SP; PIRT sebagai ijin produksi untuk produk skala rumahan. MD adalah ijin produksi industri besar skala lokal. Kode MD untuk masingmasing produk akan berbeda jika diproduksi pada daerah/wilayah yang berbeda. ML adalah ijin produksi industri besar untuk produk impor, baik berupa kemasan langsung maupun dikemas ulang. 
SP adalah sertifikat penyuluhan untuk usaha kecil dengan modal terbatas yang sudah mengikuti penyuluhan Dinas Kesehatan di tingkat kabupaten/kota.

12) Informasi Nilai Gizi atau nutrition factssebagai syaratutama pada produk pangan dalam kemasan.

13) Kode Produksi dan Masa Kadaluarsa sebagai penetapan waktu minimal dan maksimal yang dianjurkan untuk suatu produk dapat disimpan, dimana kualitas yang ditetapkan dapat diterima pada kondisi distribusi, penyimpanan, dan penjualan.

14) Barcode atau radio frequency identification (RFID)merupakan gambar kode yang mengandung informasi dan ditempelkan pada kemasan produk yang dapat dipindai secara elektronik. Barcode berisi kode informasi berupa nomor produk, nomor seri, dan nomor batch.

15) Cara Pengolahan/Penyajian Produk yang ditampilkan dengan sekedar kalimat instruksi atau dilengkapi dengan gambar langkah-langkah pengolahannya. Informasi ini dilayout pada bagian sisi samping atau belakang kemasan.

16) Logo SNI yang ditetapkan oleh Badan Standarisasi Nasional (BSN) yang berlaku secara nasional. Pencantuman logo SNI harus mempunyai sertifikasi SNI dari BSN.

17) Notifikasi Kosmetika BPOM RI, Simbol dan Kode untuk produk obat-obatan.

18) dan informasi lain pada kemasan yang diwujudkan dalam simbol-simbol khusus.

\section{Pemasaran Pariwisata Melalui Kemasan}

Sesuai dengan konsep IMC, kemasan berperan sangat penting sebagai marketing tool, karena dalam segala aktifitas pemasaran, produk akan selalu menjadi daya tarik utama. Untuk itu, dalam merancang desain kemasan harus didasari konsep yang mendukung aktivitas pemasaran, yaitu performa kemasan harus menarik perhatian konsumen ketika digunakan untuk aktifitas advertising, direct marketing, sales promotion, personal selling, interactive marketing, dan public relations.

Informasi pariwisata akan sangat efektif dalam mendukung pemasaran produk dan persaingan produk tersebut di pasar. Pada beberapa produk yang mencantumkan identitas daerah/wilayah pada kemasannya baik dalam bentuk tulisan maupun ilustrasi/foto lebih dipilih oleh konsumen sebagai oleh-oleh setelah berkunjung ke suatu daerah/wilayah tertentu dibandingkan dengan kemasan produk yang tidak memiliki identitas khusus. 

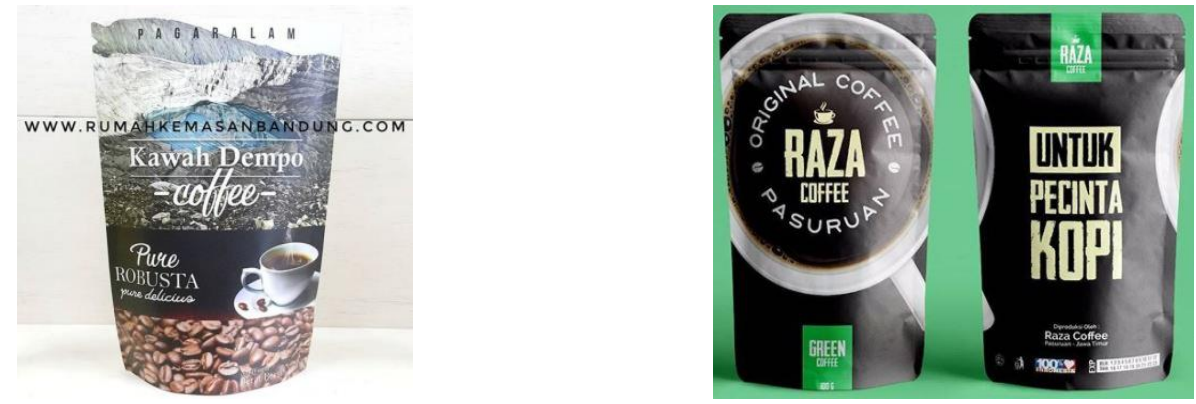

Gambar 3. Kemasan yang mencantumkan identitas daerah/wilayah wisata pada desain grafisnya (Sumber: @rumahkemasanbandung \& @assiasoft)

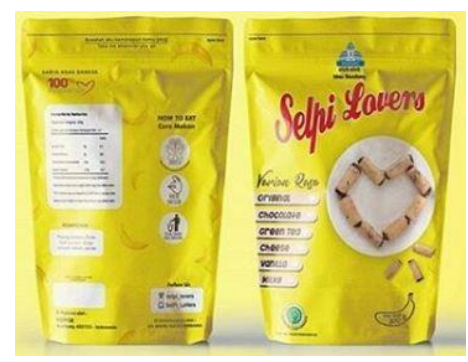

(Sumber: @kemasan_masa_kini)

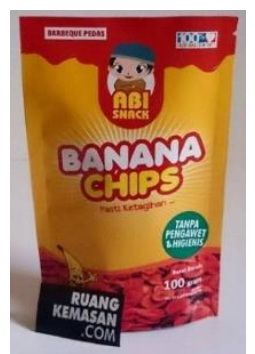

(Sumber: @ ruangkemasan)

Gambar 4. Kemasan yang tidak mencantumkan identitas daerah/wilayah wisata pada desain grafisnya

Ilustrasi yang disarankan adalah ilustrasi dalam wujud fotografi yang diolah sedemikian rupa menjadi semakin menarik ketika dihadirkan dalam area layout kemasan atau dengan ilustrasi dengan karakter drawing yang berkarakter gambar realis (seperti aslinya). Tidak disarankan menggunakan ilustrasi dengan karakter yang tidak relevan dengan daerah/wilayah wisata yang dicantumkan pada kemasan tersebut. Jika identitas daerah/wilayah wisata akan diinformasikan dalam bentuk kalimat verbal, maka penulisannya harus menggunakan font yang unik, dengan memberikan font size yang besar, dengan memberikan font color yang mencolok/kontras, atau dengan memberikan white space yang cukup luas pada area sekitar informasi daerah/wilayahwisata tersebut agar informasi tersebut bisa menarik perhatian konsumen.

\section{KESIMPULAN}

Setiap produk UKM memiliki keunikan masing-masing. Untuk itu perlu dipersiapkan suatu desain kemasan unik yang bisa merepresentasikan keunikannya tersebut. Dalam era dimana kemasan melindungi apa yang dijual, sekaligus kemasan menjual apa yang dilindungi, kemasan mempunyai 3 fungsi utama: 
1) Aspek perlindungan atas produk. Bahan baku kemasan merupakan kunci utamanya. Pemilihan bahan baku kemasan yang tepat akan membuat produk terlindungi dan akan mencapai kualitas maksimalnya dalam jangka waktu yang lama.

2) Aspek daya tarik bagi konsumen dalam mengambil keputusan pembelian. Bentuk kemasan (unik dan ergoonomis) dan desain grafis kemasan merupakan kunci utamanya. Dalam konteks mendukung pemasaran pariwisata, desain grafis yang bisa menyampaikan informasi kepariwisataan pada kemasannya akan lebih dipilih konsumen sebagai oleh-oleh. Dengan demikian, identitas khas suatu daerah/wilayah akan semakin dikenal oleh khalayak yang lebih luas.

3) Aspek legalitas. Informasi verbal yang tertera pada kemasan merupakan kunci utamanya. Informasi yang tercantum dalam kemasan harus sesuai dengan ketentuan dari lembaga pemberi legalitas, seperti: BPOM dan DepKes untuk produk makanan. Produk yang baik adalah produk yang mampu menjual dirinya sendiri. Kalimat tersebut penting kiranya karena sebaik apapun desain kemasan diciptakan untuk mengemas produk tersebut, maka akan sia-sialah semua upaya jika produk yang dikemas didalamnya tidak mampu memberikan kepuasan kepada konsumen ketika mengonsumsinya. Pemasaran pariwisata memang telah dilakukan dengan menggunakan berbagai strategi dan berbagai lini media dan keberadaankemasan produk khas daerah/ wilayah wisata bisa menjadi salah satu media promosi wisata yang sangat lekat dengan kebutuhan konsumen. Produk UKM yang telah diakui sebagai produk-produk kreatfi berbasis SDA lokal yang ditangani oleh SDM lokal pula merupakan salah satu strategi cerdas untuk menggiatkan promosi pariwisata melalui kemasan UKM daerah/wilayah tersebut.

\section{DAFTAR PUSTAKA}

\section{Buku}

Fawcett, A.E. (1993). Integrated Marketing: Marketers Convinced Its Time Has Arrived. Advertising Age

Gregory \& Hubert, B. (2010). Extrusion Coating A Process Manual. USA. Trafford Publishing. ISBN: 978-1-4072-3

Howkins \& John. (2013). The Creative Economy: How People Make Money from Ideas. $2^{\text {nd }}$ Editions. Publish by The Penguins Books. London, England. ISBN: 978-0-14197704-1

Kaihatu, T.S. (2014). Manajemen Pengemasan. Yogyakarta. Penerbit CV Andi Offset. ISBN: 978-979-29-5414-2

Kasali, R. (2007). Membidik Pasar Indonesia: Segmentasi, Targeting, Positioning. PT Gramedia Pustaka Utama. Jakarta. ISBN: 979-605-954-1

Morissan. (2010). Komunikasi Pemasaran Terpadu. Edisi Pertama. PT Prenadamedia Group. Jakarta. ISBN: 978-602-8730-18-1

Stewart \& Bill. (1997). Packaging as an Effective Marketing Tool. Pira International. United Kingdom. ISBN: 1-85802-099-9

Utama, I.G.B.R. (2017). Pemasaran Pariwisata. Yogyakarta. Penerbit CV. Andi Offset. ISBN: 978-979-29-6270-3

Wahyudi, N \& Satriyono, S. (2017). Mantra Kemasan Juara. PT Elex Media Komputindo. Jakarta. ISBN: 978-602-04-0069-3 
Vol 1, No. 1, 2018

Yaumi, M \& Damopolii, M. (2014). Action Research: Teori, Model, dan Aplikasi. Edisi Pertama. Jakarta. Penerbit Fajar Interpratama Mandiri. ISBN: 978-602-7985-80-3

\section{Artikel dalam Proseeding Seminar}

Marsh, K \& Bugusu, B. (2007). Scientific Status Summary: Food Packaging - Roles, Materials, and Environmental Issues. Journal of Food Science. Institute of Food Technologists. The Society for Food Science \& Technology. Vol.72, Nr.3, April. doi: 10.1111/j.1750-3841.2007.00301.x

\section{Artikel Majalah Ilmiah Versi Online}

Afiff, F. (2012). Pilar-pilar Ekonomi Kreatif. Rangkaian Kolom Kluster I. Binus University. Jakarta.

Riani, A.L \& Widyamurti, N. (2017). Panduan Pendirian Usaha Desain Kemasan. E-book kerjasama antara UNS Solo dan Bekraf. Jakarta. www.bekraf.go.id

\section{Artikel Media Digital}

Widodo, J. (2016). Potensi Besar UKM Industri Makanan-Minuman. 8 Juni 2016. www.presidenri.go.id. Diakses tanggal 15 Maret 2018

Widodo, J. (2016). Mendorong Produk Indonesia Menembus Pasar Global. 12 Oktober 2016. www.presidenri.go.id. Diakses tanggal 15 Maret 2018

\section{Artikel Umum}

Official website of PT Sinergy Indopack Makmur. Cengkareng - Jakarta Barat. https://www.kemasansinergy.com/produk/. Diakses tanggal 8 Maret 2018

Official website of Cetak Kemasan. www.cetakkemasanpapermetal.blogspot.co.id. Diakses tanggal 12 Maret 2018

\section{Dasar Hukum}

Undang-Undang RI No.18 Tahun 2012 tentang Pangan

Peraturan Pemerintah RI No. 69 Tahun 1999 tentang Label dan Iklan Pangan

Peraturan Pemerintah No.28 Tahun 2004 tentang Keamanan Mutu dan Gizi Pangan

Peraturan Kepala Badan Pengawas Obat dan Makanan (BPOM) Republik Indonesia Nomor : Hk 00.05.55.6497 tentang Bahan Kemasan Pangan

Peraturan Menteri Kesehatan RI No.329/Menkes/XII/76 tentang Produksi dan Peredaran Pangan 